\title{
Microfinance as the Key Factor Affecting Farmers' Investment Decision- Making: Cluster Experiences in Impasugong, Bukidnon, the Philippines
}

\author{
R.R. Real, L.A.T. Hualda, D.I. Apara and S.B. Concepcion \\ University of the Philippines Mindanao \\ The Philippines \\ P.J. Batt and R. Murray-Prior \\ Curtin University \\ Australia
}

Keywords: loan, crop production, support, risk, sustainability

\begin{abstract}
This paper focuses on how microfinance has affected the investment decision making of squash and bitter gourd cluster farmers in Impasugong in the Southern Philippines. The farmers received loans from a microfinance institution (MFI) but because of production problems farmers were not able to meet their buyers' requirements. The squash cluster disintegrated, while the bitter gourd cluster decided to diversify into onion production and to adopt organic fertilizers as a more cost effective means of production. As a result of these setbacks, both the clusters and the MFI learned some valuable lessons including; the role of microfinance in production; the risks associated with loans; and the level of support received by the farmers. Sustainability of livelihoods is the key factor that keeps the MFI and the farmers together. As the farmers aspire to maintain production, they will continue to need access to financial resources to meet their farm and family commitments.
\end{abstract}

\section{INTRODUCTION}

Ahmad et al. (2004) suggest that microfinance has evolved as an economic development approach intended to benefit low-income groups through the provision of financial services. Microfinance institutions (MFIs) target the poor through innovative approaches, which include group lending, progressive lending, regular repayment schedules and substitutes for collateral (Thapa, 2006). Through these, it is expected that the poor will be empowered to move out of poverty (Oji, 2006).

Microfinance can also be an instrument in establishing successful enterprise development if linked with other interventions such as technical training and the provision of simple business skills. However, in agriculture, microfinance presents additional risks, since farmers opt to borrow on the basis of anticipated crop production. Highly exposed to turbulent internal and external environments, which include natural disasters, a sudden decline in market prices, lower than expected yields, a lack of buyers and losses arising from poor storage conditions, smallholder farmers often experience difficulty in meeting their obligations to repay loans (CGAP and IFAD, 2006).

This case study describes how two vegetable marketing clusters in Impasugong, Southern Philippines, reacted quite differently when they found themselves unable to repay their loans.

Concepcion et al. (2006, p. 1) defined a marketing cluster as 'a group of farmers who formed together based on their capability, interest and capitalization'. By forming a cluster, the production of vegetables became possible through the financial assistance provided to the farmers by an MFI. While some crops failed due to disease, others were unable to meet the quality specifications demanded by the buyer and thus farmers received a lower than anticipated price in the local market. As a result, some farmers were discouraged, while others shifted to alternative vegetable crops. Those who shifted were provided with additional loans, thereby facilitating the repayment of the initial loan.

This study investigates how access to microfinance and problems with crop failure affected crop investment decision-making among the farmer-members of two vegetable 
clusters in Impasugong, Bukidnon, in the Southern Philippines. However, it is limited only to the group's experiences and thus, while there may be knowledge that can be applied to other smallholder farmers, there are boundaries that need to be respected. The study has only focused on the clusters' experiences and not the entire community. Furthermore, the study recognizes that there are other agencies also working in the area who are also dealing with microfinance issues.

\section{METHODOLOGY}

In the municipality of Impasugong, Southern Philippines, two vegetable marketing clusters focused on the production of squash (Cucurbita moschata Duch), locally known as kalabasa, and bitter gourd (Momordica charantia Linn.), or ampalaya. The Catholic Relief Services (CRS) assisted in the development of the clusters using the Eight-step Agro-enterprise Development process (CRS, 2007). Local Government Units (LGU), such as the Department of Trade and Industry (DTI) and Department of Agrarian Reform (DAR), also collaborated in the establishment of the clusters.

This study uses a case study methodology, with information collected from secondary information, key informant interviews, a baseline survey and a survey looking at farmer decision-making with regard to crop selection and crop rotations. The baseline survey provided information on the farmers' production and marketing protocols, while the decision-making survey provided information about the factors affecting the farmers' investment decisions.

Specifically, the Eight-step Agro-enterprise Development process (CRS, 2007) was incorporated as part of the clustering approach. It was developed as a means of enabling farmers to link with institutional markets, to assist them in becoming an organized group and to guide them in engaging with downstream market intermediaries. The process, which is largely based on action learning, facilitates the farmers' learning as they undertake agro-enterprise development. The documents prepared from these learning experiences provide the primary source of information for this study.

\section{BACKGROUND}

In the municipality of Impasugong, Bukidnon, Northern Mindanao, 15 farmers from Barangay Capitan Bayong came together to collectively market squash, while 9 other farmers from Barangay Poblacion decided to consolidate their efforts in producing and marketing bitter gourd

The squash cluster delivered their product to local buyers in Cagayan de Oro City, who then shipped the produce to Cebu. The Municipal Economic Enterprise Development Office (MEEDO) acted as the consolidator, ensuring that every week, farmers were able to supply 8 tonnes to meet their contractual obligation.

On the other hand, the bitter gourd cluster delivered their produce to the Northern Mindanao Vegetable Producers' Association, or NORMIN Veggies, in Cagayan de Oro. As a market facilitator, NORMIN Veggies was able to assure its buyers that products delivered to them by the farmers had met pre-requisite standards. The recommended weight for a single squash must be at least $3 \mathrm{~kg}$. The quality specifications for ampalaya are more stringent: $4-5$ pieces per $\mathrm{kg}$, each piece should be $25 \mathrm{~cm}$ long, with no insect damage or cracking and smooth skin.

In terms of assistance, the Kaanib Foundation was the lead institution supporting the cluster farmers in terms of technical and marketing matters. Since establishment, Kaanib has provided training for the cluster's growth and development, particularly on natural farming and technology systems (NFTS), simple bookkeeping procedures and farm exposure trips. Furthermore, through its counterpart organisation, the Kauyagan Savers Cooperative, Kaanib was able to provide the squash farmers with loans amounting to $\mathrm{PhP} 8,000-10,000$ per ha, at a flat rate of $15 \%$ over a six month period.

Kaanib was also able to assist the bitter gourd cluster farmers by providing the equivalent of PhP 10 per hill (plant) to assist in the purchase of production inputs such as seeds, fertilizers and pesticides. Each farmer was able to borrow $\mathrm{PhP} 2,000-7,000$. The 
financial arrangement was that the clusters collectively would be responsible for repaying the total amount provided to the members after one cropping season.

\section{CHALLENGES FACED DUE TO CROP FAILURES}

After only two months, or eight deliveries, the squash cluster was unable to meet their contractual obligations. Many of the farmer's crops failed due to a viral disease whereupon the leaves wilted easily and the number of flowers rapidly decreased. Replanting was not feasible as the hot weather at that time was not suitable for squash production. As the squash cluster was unable to supply its main market, farmers lost the primary outlet for their produce as the buyer went to other producers who could supply the desired volume. As a result, farmers had no choice other than to sell their produce in the local wet market, where the price was much lower.

Just like their colleagues, many of the bitter gourd cluster members also found themselves unable to repay the loan. The production of the crop was devastated by a viral disease locally termed as "pamamarako", which is similar to cucurbit aphid-borne yellow virus (CABYV). The disease caused curling, thickening and yellowing of the leaves, reducing the number of female flowers and consequently reduced fruit production (JICA TCP 3 Ilocos Norte, 2007). This decreased their expected harvest and ultimately their anticipated income.

Because of production failures, some farmers were discouraged from continuing their allegiance to the clusters because they were afraid that if they were still members, they would be asked to assist with the repayment of their debt to Kauyagan Savers Coop. As a result, the Barangay Capitan Bayong squash cluster disintegrated after only one year. Meanwhile, membership of the bitter gourd cluster in Barangay Poblacion declined from nine to six active members.

Despite the crop failure, cluster members remained unable to repay their debts for a number of other reasons. Even although most farmers were cultivating more than one crop, the prices they were receiving for cucumbers, sweet peas, carrots and sweet pepper were often insufficient to recover the costs of production. In the absence of alternative buyers, they were forced to sell to the local market, where, because of the additional supply and insufficient demand, the prices offered were substantially lower.

\section{FARMER RESPONSES TO THE ISSUE}

As opportunities abound for smallholder farmers in Impasugong, the bitter gourd cluster was able to revive the organization. They diversified into bulb onion (Allium cepa L.) production, which was made possible through the efforts of CRS and a food service company that offered to buy the onions from the cluster.

However, in producing onions, there are certain requirements that must first be fulfilled. One of these is that the crop must be grown using rain shelters to protect the crop from damaging wind and rain which can constrain both the production and the quality of the resultant crop. These facilities have been used in Impasugong to minimize flooding and water logging (Palada et al., 2003) and to minimize the incidence of disease and fruit cracking (Nalundasan et al., n.d.)

A rain shelter is essential in Impasugong as the region has a Type III climate. This means that there is a relatively short dry season that usually lasts from February to April, with rainfall occurring regularly throughout the remainder of the year (Moong, 2005). The resultant high humidity means that without protected cropping, the crop will easily rot.

The food service company required onions with a minimum diameter of $7.5 \mathrm{~cm}$, for which they were prepared to pay PhP 38 per $\mathrm{kg}$, delivered to NORMIN Veggies in Cagayan de Oro City. In cases where the product did not meet the required specifications, the onions were sold to the local wet market.

Those farmers who showed an interest in producing bulb onion were provided with at least one rain shelter. However, Kaanib insisted that the rain shelters were provided as a loan to the farmers. With the cost ranging from $\mathrm{PhP} 7,500-10,000$ per unit, 
the amount to be deducted by the cluster from the farmers' returns was equivalent to the depreciation rate in one year, which ranged from $\mathrm{PhP} 625-833$.

\section{CHANGES TO THE FARMING SYSTEMS}

Most of the farmers who availed themselves of the opportunity of a loan to construct a rain shelter were the same farmers who were unable to repay their debt as a result of crop failure. Each of them had a total debt of between PhP 9,500-17,000. For those farmers who chose to supply bulb onion through the cluster, this did not reduce their capacity to repay as they already had two markets for this product: one for the institutional buyer and one for the local market.

Farmers were highly motivated as they now had a constant supply of product and thus the potential to discharge their obligations promptly. Survey evidence confirmed that most farmers were cultivating multiple crops including bulb onion and leafy vegetables such as pechay (Brassica rapa L.), so that they would have a continuous flow of income.

Cluster farmers were also executing cost effective measures to reduce their costs of production through the application of organic fertilizers. The Kaanib Foundation had trained the farmers how to make concoctions derived from different fruits and plants and other local products as an alternative to conventional fertilizers. As a result, farmers were now using fermented fruit juice (FFJ), fermented plant juice (FPJ), indigenous microorganisms (IMO), chicken dung and vermicompost as part of their crop nutrient management protocols. These products were as effective as conventional fertilizers, but the ingredients were found mostly in their immediate locality and more importantly, the cost was much lower: $\mathrm{PhP} 35-80$ a litre for liquid-based fertilisers and $\mathrm{PhP} 1.63-6.25$ per $\mathrm{kg}$ for solid-based fertilisers. With these, farmers could save on input costs and thus redirect the funds to meet their financial obligations.

Although many farmers in Impasugong embraced bulb onion production, they did not discount the possibility of returning to bitter gourd production, the root cause of their initial indebtedness. In fact, one farmer opted to continue, and he was able to find a variety that was resistant to the viral disease. As he was able to achieve high prices for his output, other members of the cluster began to revitalize their bitter gourd production using the same disease-resistant variety.

\section{LESSONS LEARNED}

Farmers learned a number of lessons in their attempt to make their livelihood more sustainable. Firstly, microfinance was considered essential in the growth and development of the cluster. As most farmers do not have sufficient financial capacity, any capital assistance is highly appreciated. Secondly, because of the debt they acquired, farmers' attitudes and practices became linked to the use of microfinance products. Thus, engaging in other production activities like investing in other crops, or the use of highyielding and disease-resistant varieties, was more feasible for them. These ventures increase the probability that they can settle their obligations with the MFI in an expedient manner, but there are downsides if they fail. Thirdly, communication is essential between the MFI and its clients.

Farmers who belonged to the squash cluster abandoned the cluster because of the fear that they may have to repay their unpaid debts immediately if they continued to work as a cluster. According to Kauyagan Savers Coop, few farmers showed up in the office to settle their obligations. With this, the squash cluster overlooked the possibility that they could expand their production towards other cash crops.

As for the facilitators, gaining incentives was the critical reason given by the farmers who decided to accept financial assistance from the MFI. At the start of the agroenterprise planning process, farmers were given an assurance that their products would be sold to an existing market and that investing in those crops identified would generate a positive return. These advantages motivated the farmers to organize themselves into a cluster, rather than to operate as individuals. 
Another key lesson drawn from the farmers' experience was the level of support they received from various organizations. In this case, the MFI extended their capital assistance to the farmers, starting from the initial agro-enterprise plan of producing bitter gourd and squash, to supporting crop diversification. Since these alternative crops were easily marketable, farmers could expect higher returns, which proved valuable in meeting their obligations with the MFI to whom they were indebted.

\section{CONCLUSION}

The study has pointed out that microfinance can affect the investment decisions made by smallholder farmers, particularly in the municipality of Impasugong, Southern Philippines. As part of a cluster, the farmers' behaviour was influenced by the assistance provided to them, like diversifying into other crops and employing more cost effective crop nutrient application techniques. This enabled them to grow crops that had the potential to generate more income and thus to repay their financial obligations.

From the perspective of the MFI, their willingness to extend additional capital assistance to those farmers who were unable to meet their initial repayments due to crop production problems ultimately placed them in a better position to recover their initial loans and to establish a more positive long-term relationship with their clients. Of course, there was a risk that these renewed investments would also fail and that they would have a greater non-performing loan.

Most importantly, for the smallholder farmers, most of them rely entirely on farming as their only source of income. Thus it was essential for them to have financial resources available to support any investment decisions they may make in the future. This particular scenario is what keeps the farmers and the MFIs together. As the farmers aspire to maintain their production, they will continue to need access to financial resources to meet their farm and family commitments.

\section{ACKNOWLEDGEMENT}

The support of the Australian Centre for International Agricultural Research Component 4 (ACIAR-C4) project is gratefully acknowledged. The assistance from Kaanib Foundation Inc. (KFI) and Kauyagan Savers Cooperative in the conduct of this study is also appreciated. In addition, the eight-step procedure in clustering approach formulated by the Catholic Relief Services (CRS) is duly acknowledged.

\section{Literature Cited}

ACIAR Project Component: HORT/2007/066/2. Protected Vegetable Cropping. http://www.protectedcropping.com/.

Ahmad, Shahzad, Muhammad Sajid Naveed and Abdul Ghafoor. 2004. Role of Micro Finance in Alleviating Rural Poverty: A Case Study of Khushhali Bank Program in Rahim Yar Khan-Pakistan. International Journal of Agriculture and Biology. 1560 8530/2004/06-2-426-428.

Catholic Relief Services-Philippines. 2007. The Clustering Approach to Agroenterprise Development for Small Farmers: The CRS-Philippines Experiences. A Guidebook for Facilitators. Davao City, Philippines.

Concepcion, S.B., Digal, L.N. and Uy, J.C. 2007. Keys to inclusion of small farmers in the dynamic vegetable market: The case of NorminVeggies in the Philippines. Regoverning Markets Innovative Practice series, IIED, London.

Consultative Group to Assist the Poor (CGAP). 2006. Emerging lessons in agricultural microfinance: Selected case studies. International Fund for Agricultural Development.

Japan International Cooperation Agency - Technical Cooperation Project (JICA TCP 3 Ilocos Norte). 2007. Technoguide for Ampalaya Production in Ilocos Norte. http://www.openacademy.ph/index.php?option=com_content\&task=view\&id=1084\&I temid $=526$.

Moong, Francisco A. 2005. Philippines: Country Pasture/Forage Resource Profile. http://www.fao.org/ag/AGP/AGPC/doc/Counprof/Philippines/Philipp.htm 
Nalundasan, M.A., Ruguian, R.C. and Alpuerto, V.V. (n.d.). Off-Season Tomato Production Technology. Agriculture and Fisheries Research and Development Information System, Mariano Marcos State University, Philippines.

Oji, K.O. 2006. Transformation of micro-finance schemes from subsistence living to small-scale enterprises in Nigeria: Analysis of policies for integration of science and technology into the client's activities. United Nations Educational, Scientific and Cultural Organization, France.

Palada, M.C., Roan, Y.C. and Black, L.L. 2003. Rain Shelters for Tomato Production in the Hot-Wet Season. International Cooperators' Guide. AVRDC World Vegetable Center.

Thapa, G. 2006. Sustainability and Governance of Microfinance Institutions: Recent Experiences and Some Lessons for Southeast Asia. Asian Journal of Agriculture and Development, Vol. 3, Nos. 1-2.

Vermicast. Wastebusters Trust Canterbury. http://www.wastebusters.net.nz/. 